\title{
Parties, Promiscuity and Politicisation: Business-political networks in Poland
}

\begin{abstract}
Research on post-communist political economy has begun to focus on the interface between business and politics. It is widely agreed that informal networks rather than business associations dominate this interface, but there has been very little systematic research in this area. The literature tends to assume that a politicised economy entails business-political networks which are structured by parties. Theoretically, this article distinguishes politicisation from party politicisation and argues that the two are unlikely to be found together in a post-communist context. Empirically, this paper uses elite survey data and qualitative interviews to explore networks of businesspeople and politicians in Poland. It finds substantial evidence against the popular idea that Polish politicians have business clienteles clearly separated from each other according to party loyalties. Instead, it argues that these politicians and businesspeople are promiscuous. Since there seems to be little that is unusual about the Polish case, this conclusion has theoretical, methodological, substantive and policy implications for other postcommunist countries.
\end{abstract}

7,685 words (excluding this title page, including abstract, notes and bibliography)

Final draft for the EJPR, 3 November 2003

\author{
Iain McMenamin \\ Lecturer in Government \\ Dublin City University \\ Collins Avenue \\ Dublin 9, Ireland \\ Tel: +35317008072 \\ Fax: + 35317005446 \\ Email: iain.mcmenamin@dcu.ie
}

Acknowledgments: The quantitative data in this paper was provided by Jacek Wasilewski of the Institute of Political Studies, Polish Academy of Sciences, co-ordinator of the State Committee for Scientific Research project no. H01F00912. Zbigniew Drag familiarized me with the dataset. Jouni Kuha provided invaluable statistical advice. Disagreement with Vesselin Dimitrov and Roger Schoenman was very productive. All remaining errors are mine. 


\title{
Parties, Promiscuity and Politicisation: Business-political networks in Poland
}

\begin{abstract}
Research on post-communist political economy has begun to focus on the interface between business and politics. It is widely agreed that informal networks rather than business associations dominate this interface, but there has been very little systematic research in this area. The literature tends to assume that a politicised economy entails business-political networks which are structured by parties. Theoretically, this article distinguishes politicisation from party politicisation and argues that the two are unlikely to be found together in a post-communist context. Empirically, this paper uses elite survey data and qualitative interviews to explore networks of businesspeople and politicians in Poland. It finds substantial evidence against the popular idea that Polish politicians have business clienteles clearly separated from each other according to party loyalties. Instead, it argues that these politicians and businesspeople are promiscuous. Since there seems to be little that is unusual about the Polish case, this conclusion has theoretical, methodological, substantive and policy implications for other postcommunist countries.
\end{abstract}

\section{Introduction}

In the immediate post-communist years researchers were preoccupied with the speed with which the state and the economy should be separated from each other. Most scholars operated under the assumption that the "grabbing hand" of the state was a threat to economic development (Shleifer \& Vishny 1998). More recently, it has been realised that politics and the economy cannot be kept completely separate from one another. The great challenge is to establish an efficient interface between the two (Stark \& Bruszt 1998; Olson 2000; Hellman, Jones \& Kaufmann 2000). In order to do so, it is necessary to understand the currently prevailing relationship between politics and business. Most of the work on this subject deals with business associations. In the Polish case (Jasiecki 1997; McMenamin 2002; Draus 2000), and elsewhere in Eastern Europe (Padgett 2000), the principal conclusion of the literature is that business associations are quite weak in comparison with informal networks. There is a tendency to conclude that political parties 
structure these informal networks. It is widely assumed that political parties maintain clienteles of businesspeople who have little or no relationship with other political parties (Frentzel-Zagórska 2000: 225; Schoenman 2002a; Ágh 1998: 112). Theoretically, this article argues that previous research ignores the possibility that parties and businesspeople have contrasting incentives. Exclusive relationships are in the interest of parties but businesspeople have an interest in maintaining good relationships with all parties. Empirically, the paper finds that politicians have not managed to restrict the personal connections of senior businesspeople to one political party or bloc. Most of the existing literature is based on informed speculation or a handful of case studies. This paper uses data from an elite survey conducted by the Institute of Political Studies of the Polish Academy of Sciences (ISP) and qualitative interviews conducted by the author to explore the nature of these informal networks. The theory and methodology of this paper as well as its conclusions and policy implications apply to other post-communist states.

The next section presents a theoretical critique of the party-politicisation hypothesis and argues that Poland is a relatively typical case with regard to hypotheses evaluated in the article. The paper then goes on to present complementary quantitative and quantitative evidence on networks of businesspeople and politicians in Poland. The conclusion emphasises the relevance of this research to other post-communist states, in terms of both academic research and the battle with corruption.

\section{Theoretical Context}

Firstly, this section defines the key concepts and hypotheses of the article. It continues with a critique of the popular party politicisation hypothesis regarding post-communist business-political networks. Finally, it assesses some key variables in Poland and elsewhere in the region, arguing 
that the case for party politicisation is problematic and that there seems to be little that is distinctive in the Polish environment for business-political networks.

\section{Concepts and hypotheses}

Here, politicisation is defined as the ability of the state to directly influence the behaviour of individual enterprises. In this sense, it is a feature of the state, not of networks. This politicisation is a different, and more intense, type of state intervention than that which affects only general classes of enterprises. There are two dimensions to post-communist politicisation: direct and indirect. Direct politicisation refers to state ownership. The influence of state ownership goes well beyond the category of traditional state-owned enterprises to encompass various ownership forms, including those in which the state has a substantial minority stake and ownership of firms by various parastatal bodies (OECD 1997: 65-67). Indirect politicisation refers to a wide variety of devices which can give firms a vital competitive advantage, or, probably more often, shield them from competition. These include derogations, licences, public procurement, quotas, etc. (Staniszkis 1998; Drag 1999: 62-69; Schoenman 2002b). The commonplace observation that there is a high level of politicisation in post-communist economies underlies the executive hypothesis.

The executive hypothesis simply states that politicians who have held positions in the executive are likely to have better connections with businesspeople than those who have not. Moreover, politicians with executive experience are likely to know a different group of businesspeople than those who have never held high office. The association between experience in senior executive positions and connections with businesspeople is likely to be especially strong in a highly politicised economy. It is often assumed that the party politicisation hypothesis naturally follows from the executive hypothesis. 
The party politicisation hypothesis states that both political and business leaders should have connections to a particular group of businesspeople loyal to, or dependent on, a particular political party. Under party politicisation, phrases like "he's an SLD man" tell us most of what we need to know about the political connections of a businessperson (Frentzel-Zagórska 2000: 225; Schoenman 2002a; Ágh 1998: 112). This hypothesis does not contain any assumptions about the origin of such affiliations. For example, they could be childhood friendships, communist-era connections or instrumental connections formed in the post-communist era. The logic behind the party politicisation hypothesis is simple. Given that parties control the executive and the executive controls a politicised economy, business-political networks should be structured by political parties. That is to say, businesspeople and politicians are loyal to, or dependent on, political parties and their networks and do not cut across networks structured by political parties. The alternative to the party-politicisation hypothesis is the promiscuity hypothesis. It predicts that networks of businesspeople and politicians will not be structured by political parties (Jasiecki 2001: 158; Wasilewski 2000: 216). Businesspeople form connections with politicians of different parties and politicians form connections with businesspeople who are also close to their political adversaries. While the party politicisation and promiscuity hypotheses are alternatives to each other, both are consistent with the executive hypothesis, even though the executive hypothesis entails neither of them. 


\section{Critique of the party politicisation hypothesis}

The party politicisation hypothesis tends to assume that politicians and businesspeople have congruent interests. The argument is as follows. A high level of politicisation means that there are very strong incentives for firms to develop political connections and there are great opportunities for well-placed politicians to develop connections to the business class. Furthermore, the expense of electoral competition and the financial resources of business mean that there are very strong incentives for political parties to develop connections to the business class. However, this article argues that strong incentives for politicians and businesspeople to get to know each other and exchange resources does not necessarily mean that networks of businesspeople and politicians will be structured by parties.

Businesspeople and political parties in capitalist democracies have conflicting interests. Unless one party seems likely to stay in power for the foreseeable future loyalty to one particular party is not a sensible long- or medium-term option for any businessperson. A Polish political lobbyist says:

I do not think [that businesspeople are associated with political parties]. Not unambiguously in the sense of someone who is in business and is known to be associated with a political party. What is much more common is someone who searches for contacts with politics ... Since the government has changed every four years it makes no sense to declare unambiguously for one party. Of course, they are going to try and arrange good relations with different politicians (Interview: Dziedzic, Warsaw, 1 July 2002).

Of course, political parties have an interest in ensuring that businesspeople support only their party and do not, instead, or in addition, support their competitors. The outcome then rides on the extent to which political parties can punish businesspeople who support other parties. The party politicisation hypothesis assumes that politicians can punish disloyal businesspeople while the promiscuity hypothesis assumes they cannot do so. 
Just as the conflicting interests of business and parties arise from the uncertainties of the democratic process, so do serious limitations on the ability of parties to punish disloyal businesspeople. When parties are out of government, they have little to offer businesspeople and are unlikely to be able to stop business seeking favours from their political opponents. Even in government, it is questionable whether any party in a competitive environment would be in a position to turn down the support of a businessperson who had previously supported one of their political opponents.

In assuming parties can punish business, the party politicisation hypothesis also seems to make cavalier assumptions about two other key features of the context of business-government relations: firstly, the extent to which the post-communist executive is entirely controlled by parties, and secondly, the relative importance of direct and indirect politicisation. If the executive is not controlled by parties then businesspeople can focus on developing connections with individual ministers. Financial benefits can be channelled to individuals who will then have no particular interest in punishing businesspeople for their disloyalty to a party. Individual decision-makers become more important as the level of administrative discretion increases and the level of party discipline decreases.

The party politicisation hypothesis is partially predicated upon an assumption that the importance of direct politicisation dwarfs that of indirect politicisation. The membership of the boards of firms is transparent and the process of appointment is one which parties can relatively easily centralise and control. New governing parties can bring about wholesale changes in the boards of firms in which the state is a shareholder. Nevertheless, this control is dependent upon the importance of party government. Appointments can easily be made by individual ministers from 
their own personal clientele rather than from amongst party loyalists. The mechanisms of indirect politicisation seem more difficult for parties to control. Not only are they more complex, diverse and opaque than appointments, they are much more difficult to reverse. Privatisations are an obvious example.

This section has acknowledged that a high level of politicisation of the economy presents a great potential for party politicisation of business-political networks. However, party politicisation is dependent on a series of intervening variables: turnover in government, party control over the government (which is in turn dependent on administrative discretion and party discipline) and the relative importance of direct and indirect politicisation. The next section focuses on an assessment of these variables in East-Central European post-communist states, in general, and in Poland, in particular. Before that is done, it is necessary to address the popular thesis that ideology is a vital factor in the structuring of business-political networks.

\section{Key variables in Post-Communist Europe and Poland}

In some party systems, like the USA and UK, parties have been traditionally identified as the "party of business" for ideological reasons and "right-wing" has automatically meant "probusiness". However, in Poland, positions on secularism and liberalism versus religion and traditionalism are much more strongly associated with the classification of parties as left, right and centre than economic policy (see Figure 1). Another element of the Polish left-right scale is the genealogy of parties in relation to the previous regime. The Democratic Left Alliance (SLD) claims a social-democratic identity but is more clearly defined by its secular, liberal attitude and its genesis in the United Workers' (communist) party. The right-wing Solidarity Electoral Action was a loose alliance that had little in common other than a vague traditionalism and a hatred of communism. The centrist Freedom Union is a liberal party in the sense that it is pro-market and 
secular. It has its roots in the opposition to communism. The last vital political player is the Peasant Party. It is firmly linked to its peasant constituency, espouses moderately nationalist economics and has a background in both the communist regime and the anti-communist movement. It is perceived as left of centre, in the Polish understanding of the left-right continuum.

High levels of politicisation tend to override ideology as a factor in explaining links between parties and business. A well-known example, and one which is often compared to East-Central Europe, is Italy (Jasiecki 2000). In the era of Christian Democratic dominance, Italy was highly polarised on economic policy, but all parties, including the communists, had close connections to business because the high level of politicisation presented opportunities for both businesspeople and politicians which the competitive environment meant neither could pass up (Golden \& Chang 2001). The rest of this section analyses variables which intervene between politicisation of the economy and party politicisation of business-political networks in an East-Central European context. Poland seems to be broadly similar to its neighbours in respect of these variables.

[Figure 1 about here]

There is a notoriously high turnover at elections in East-Central Europe. In Poland, no government has been re-elected (Lewis 2000: 62-67). There is a consensus that individual decision-makers are allowed a huge amount of discretion in post-communist states. Thus, party politicisation is faced with a context in which business and politicians have conflicting interests and it is therefore necessary to examine the extent to which parties can punish disloyal businesspeople. Substantial discretion is an accepted feature of post-communist administration. Comparative governance data shows Poland to be similar to most of its neighbours in this regard (World Bank 2003). In Poland (Rzeczpospolita 2000b), and elsewhere, it is accepted that this 
discretion provides great potential for individual decision-makers to privilege individual enterprises. Moreover, it is doubtful whether post-communist parties are strong enough to control most of their ministers most of the time. It is agreed that parties in this region are generally weak and undisciplined (Lewis 2000: 94-119) and once again Poland is no exception (Szczerbiak 2000).

The enduring importance of state ownership, albeit in new forms, is a well-established theme of post-communist political economy. If the Polish State is significantly different in this area it is because it has retained an even greater influence than many of its neighbours. Schoenman's data on board memberships shows the Polish economy to be subject to greater direct politicisation than supposed reform laggards Bulgaria and Romania (Schoenman 2002b). Direct politicisation is assumed to work in favour of the party politicisation of business-political networks, since it is assumed that only party loyalists will be appointed to boards. Of course, this takes for granted that appointments are made centrally by a party leadership rather than by loosely controlled ministers trying to promote their own personal clientele. There is anecdotal evidence for both sorts of appointments in Poland, although most press coverage does tend to talk about party politicisation. A good example is the controversial state insurance giant PZU (Rzeczpospolita 2000a). Survey evidence casts doubt on the link between appointments and party politicisation. The ISP survey described below found that over 90 per cent of senior businesspeople claimed to have never received a political nomination to a business position (Drag 1999: 71). Even if this figure is exaggerated it seems unlikely to be totally misleading, since respondents had no problem volunteering sensitive information in response to other questions. Finally, it is very obvious that much of the state's influence, in Poland and elsewhere, is transmitted indirectly through licences, public procurement, tax breaks, grants, etc. Although these mechanisms are well known, it is 
much rarer for them to be presented as the basis of party-politicised networks of businesspeople and politicians.

The two conclusions of this section are that the party-politicisation hypothesis is theoretically and empirically problematic and that there seems to be little that is unusual in the environment that surrounds business-political networks in Poland. Therefore, the next sections directly investigate the structure of business-political networks in Poland, and the conclusion points out the implications of the Polish case for other post-communist states.

\section{Quantitative Evidence}

This section is organised as follows. Firstly, a detailed account is given of the data used in the paper. Secondly, regression analyses of this data are used to assess explanations for the variability in how well known the leaders are. Thirdly, multi-dimensional scaling is used to assess the location of the leaders in the overall pattern of connections between business and politics. Fourthly, cluster analyses are presented. These serve the purpose of corroborating or questioning the statistical results from earlier sections.

Data

It should be noted at the outset that, although the data used in this section is excellent for investigating elite networks, it is not the sort of data which is used in the type of formal network analysis which is popular in sociology and of increasing importance in political science (Hughes, John \& Sasse 2002; Knoke, Pappi, Broadbent \& Tsujinaka 1996; Heinz, Laumann, Nelson \& Salisbury 1993). In 1998 a wide-ranging elite survey was undertaken by ISP. For the business section of the survey, 300 businesspeople were selected from the lists of the 500 biggest Polish firms published by Polityka (quality weekly) and Gazeta Bankowa (equivalent of the Financial 
Times). 194 interviews were carried out making for a response rate of 64.6 per cent. Since two members of some firms were interviewed there is data for 144 businesses. In order to eliminate selection bias most of the following analysis is based on the firm. Where there were two respondents from one firm, one of them has been randomly selected. The survey contained questions about how well respondents knew 35 political and economic leaders. The list of 35 was not drawn up systematically but seems representative of Poland's most powerful people. 22 are politicians and 11 business figures. One member of the list was a newspaper editor and another was the governor of the central bank. The 35 leaders are listed in the appendices.

Respondents were asked to rate how well they knew each of the thirty-five leaders. Missing data on these items reduces the data set of firms to 135. The survey contained five levels: knows very well, knows fairly well, has had contact with, knows the name, has never heard of. For the present analysis the last two categories are conflated. The last category is not very meaningful since the leaders are amongst the best-known people in the country. In addition to being substantively problematic this category was not chosen very often by respondents. On average only 5.3 per cent of respondents claimed not to have heard of the leader in question. If one businessman (Sobolewski) who was not recognised by 64.1 per cent is removed the average falls to 3.43 per cent. The analysis below is based on the assumption that interval-level data is being used. Normally, five categories are assumed to be necessary for interval-level measurement. However, in the case of national elites the tiny difference between not having heard of someone and merely knowing their name, as opposed to levels of actual contact, seems a greater violation of the assumption of interval-level measurement. This data is called "raw familiarity" in the analysis below.

Raw familiarity is combined into an aggregate score which aims to measure how well the respondents know the individual leaders. This is called "average familiarity" and it is simply the 
mean raw familiarity score for any individual leader across the whole sample of 135 respondents. This score measures how many respondents know the leader, as well as how well they know him. Independent variables derived from the hypotheses outlined above were also measured. The first of these assigns a left-right score to each leader on a scale of 0 to 10 . The politicians have been given the mean score for the supporters of their party from the Polish General Election Survey of 1997. ${ }^{1}$ The business leaders have been randomly assigned a value from a normal distribution based on the mean and standard deviation scores from the ISP sample of business elite respondents. ${ }^{2}$ The various rumours surrounding the partisan identification or association of the business leaders were judged to be too unreliable or ambiguous. For example, Andrzej Arendarski of the Polish Chamber of Commerce was a member of a right wing and centrist government in the early 1990s but is now often associated with the Democratic Left. Decisions on the measurement of the left-right placement of the business leaders do not make a big enough difference to change the interpretation of statistical results. Extreme left and extreme right positions were assigned to all business leaders without substantially changing the results of the regression analyses presented below. The second variable aims at evaluating the executive hypothesis. It is measured by the sum total of months for which the leaders have held cabinet posts, the presidency or the governorship of the central bank since the formation of the first noncommunist-led government in 1989 (European Journal of Political Research 1990-99; Rzeczpospolita). This measure is somewhat crude since junior ministers and heads of agencies would also have met many members of the business elite in the performance of their duties. Nonetheless, the measure clearly excludes those with merely party political and legislative experience who would have had little chance to directly influence enterprises. The third independent variable simply distinguishes those who are primarily businesspeople from those who are not. 
The definitions of the variables, together with summary statistics, are presented in Table 1.

[Table 1 about here]

What separates the well known from the not-so-well-known?

The hypotheses about connections between politics and business contain two basic elements: firstly, how well known a leader is and, secondly, the location of a leader's connections within the overall pattern of connections between politics and business. This section deals with the first of these elements. It does so by simply assessing to what extent key variables can explain how well known a given leader is. This was done by means of a regression analysis, the results of which are presented in Table 2 .

[Table 2 about here]

The equation has a $\mathrm{R}^{2}$ figure of over 0.35 . This means that the model can account for over 35 per cent of the variance in the dependent variables. It, of course, also means that almost two-thirds of the variance is left unexplained. The main conclusion of the analysis is that the executive variable is by far the best predictor of how well known the leaders are. Also, the equation indicates a much weaker relationship between left-right placement and how well known the leaders are. This supports the post-communist hypothesis since the more left wing a leader the better known he is likely to be. The right-wing politicians, who are much less well known than other politicians, drive this relationship. If they are excluded left-right placement is no longer statistically significant. The isolation of the right wing is probably substantially a result of the timing of the survey. In mid-1998 the right wing had just returned to power in the September 1997 election after four years without any parliamentary representation. Therefore, it is no surprise that their connections with the business elite are shown to be weaker than those of the left-wing politicians 
who had been in power for the previous four years. This seriously attenuates the support the data gives to the post-communist hypothesis.

The second element of the hypotheses is the location of a leader's connections in the overall pattern of connections between business and politics. Most simply put, this is about who knows the leaders. A useful method for investigating this issue is multi-dimensional scaling.

\section{Multi-dimensional Scaling}

This ISP data can be used to calculate the social distance between the thirty-five leaders as measured by their connections with the wider business elite. This was done in a number of stages. First, a leader-by-businessperson matrix was constructed (35 leaders by 135 businesspeople), whose cell entries contained the four levels of familiarity reported by each business representative for each leader. Secondly, correlation coefficients (Pearson's r) were calculated for all pairs of leaders, with the 135 businesspeople as the number of cases. The higher the correlation the greater the similarity between those two columns in the matrix. This produced a $35 \times 35$ matrix. Finally, the matrix was submitted to the ALSCAL (Alternating Least Squares) nonmetric Euclidean multidimensional scaling routine in the Statistical Package for the Social Sciences. The purpose of this procedure is to try to represent the data in the correlation matrix by a simple geometrical model or picture. Data points close to each other represent individuals who are known and not known by the same businesspeople from the sample of one hundred and thirty five. This is an exploratory technique and produces no model, or single equation, which sums up the data. The number of dimensions in the final scaling solution was selected by identifying an "elbow" in a plot of the number of dimensions in a solution and the stress level, stress being a goodness-of-fit statistic. After the elbow the rate of decrease in stress achieved by the addition of further dimensions itself decreases. The selected solution has four dimensions. 
As an aid to interpretation, regression analyses were carried out using the scores on the scaling dimensions as dependent variables. The results of regression analyses of all the independent variables upon each of the four dimensions from the scaling solution are presented in Table 3 . It is important to note that these regressions are being carried out on the results of a scaling solution, not on raw data. This means that statistically significant results are not as substantively significant as they would be with raw data.

[Table 3 about here]

The most obvious characteristic of the multi-dimensional scaling solution is its lack of structure. Even with four dimensions the stress value is still only a "fair" 0.13 . Dimension 3 completely defies interpretation. Dimensions 2 and 4 are both substantially unexplained by the variables. The highest scores on dimension two belong to better-known right-wingers and the highest scores on dimension four belong to better-known left-wingers. This favours the party politicisation hypothesis. However, again, this is largely driven by the isolation of the right wing. The first dimension is the only one amenable to straightforward interpretation. Since average familiarity is unimportant it is a relatively pure measure of the location of individuals in the elite network. It predicts a clearly separate location for business leaders. This dwarfs the impact of the left-right effect on this dimension. Once again, the left-right effect disappears when the right-wingers are left out.

The lack of structure of the solution means that it favours the promiscuity hypothesis most of all. The importance of the contrast between business and political leaders also undermines the party politicisation hypothesis. If this hypothesis were true, businesspeople would be associated with 
political groups rather than forming a group of their own. However, three of the dimensions have significant left-right effects. This is driven by the right-wingers' position. The solution cannot distinguish between the business clienteles of leftist, centrist and peasant politicians. It should not be forgotten that the isolation of the right wing is probably somewhat exaggerated by the timing of the survey. In the next section a cluster analysis is employed with the aim of corroborating or questioning the results obtained so far.

\section{Cluster Analysis}

The cluster analysis performed in this section is also based on the correlation matrix described at the beginning of the previous section. Cluster analysis attempts to classify the leaders with the most similar profiles of connections with the business elite into groups. Single and complete linkage are the only methods suitable for a correlation matrix. The 'chaining' effect of single linkage can underestimate the number of clusters in a dataset. Therefore, complete linkage is the method of cluster analysis used here. The dendrogram which identifies the exact membership of each cluster and allows the reader to assess the selection of the number of clusters is presented in the appendices. In Table 4 an attempt is made to interpret the clusters by relating them to the independent variables used in the previous sections.

[Table 4 about here]

The first cluster consists of five right-wing politicians, all with below average connections to the business class, three of whom have executive experience and two of whom do not. This confirms the isolation of the right wing. The second cluster consists of the 23 individuals, almost twothirds of the leaders. In terms of connections with the businesspeople, 14 are above average and nine below average. 17 have executive experience and six do not. Four are businesspeople, six are left-wingers, five are centrists, three are peasants, two are right wingers, one is the leader of 
the Union of Labour party, four are businesspeople and the governor of the central bank and a newspaper editor are also included. This large, politically diverse cluster confirms the lack of structure in the overall elite network and the weakness of the party politicisation hypothesis, beyond the isolation of the right-wingers. The connections of the peasant, centrist and leftist politicians with the business class cannot be distinguished from each other. This cluster is a confirmation of the promiscuity hypothesis. The final two small clusters consist of 7 business leaders. Five have below average connections with the overall business elite while two are above average. None of the seven has executive experience. This confirms the finding that some of the business leaders have clienteles that are separate from those of the politicians. This is inconsistent with the party-politicisation hypothesis. The fact that five business leaders have below average connections to other businesspeople is echoes the earlier finding that executive experience is a powerful predictor of who among the leaders is best known.

The cluster analysis is fully consistent with the results of the other types of statistical analysis. Overall, the quantitative evidence tells a coherent story. There is a marked lack of structure in the connections of the leaders to the business class which means that the data most strongly supports the promiscuity hypothesis. Party politicisation is only of importance because of the isolation of the majority of the right-wing politicians. Some business leaders have clienteles amongst the wider business elite which are clearly separate from those of politicians. These separate business leaders are partly distinguished by their relatively weak connections to other businesspeople in comparison to non-right-wing politicians: this is evidence for the executive hypothesis. The survey is representative and this is a good reason to believe the story told by the quantitative data. However, the fact that lack of structure is the most salient feature of the analysis raises the possibility that the results simply reflect the limitations of the data or the statistical methods. The 
quantitative evidence for the promiscuity hypothesis is strong but it is only negative. The next section presents positive evidence in favour of the promiscuity hypothesis.

\section{Qualitative Evidence}

The evidence presented in this section is based on thirty interviews carried out in Polish and English in 1999, 2000 and 2002. Eighteen interviewees are senior representatives of what are generally regarded as Poland's five most influential business associations (Jasiecki 1997: 177; Businessman July 1998: 69; Kozek 1999: 86; Dzwończyk \& Sobczyk 1995: 153-154). They come from the full range of backgrounds under the communist regime (opposition, old regime, émigré, private business, intelligentsia) and represent a wide range of sectors, excluding the special case of agriculture (state, private, privatised, small, large, sundown, sunrise, mining, manufacturing, services). Eight politicians representing the main political options in the 19972001 parliament and with a particular interest in business and business were also interviewed as were three professional political lobbyists and a trade unionist. Thus, the sample is quite representative of Poland's business and political elite. The interviews lasted forty-five minutes on average and were semi-structured. In several of the interviews, respondents who had been asked questions relating to quite different topics volunteered evidence relating to the hypotheses in this paper. The fact that the evidence was volunteered increases its validity substantially. As regards those who did not suggest the topic themselves, the discussion was begun with a straight question, "Are members of the Polish business elite associated with particular political parties?"

All of the business representatives claimed to be "apolitical" but by this they meant they were not linked to any particular party, not that they had no connections with the political system. In addition to refusing to identify themselves as linked to a party, business representatives struggled to identify most of their political and economic rivals as closely associated with one particular 
party. Respondents mentioned a variety of ways in which this non-partisan politicisation of the business elite was manifest. Business leaders knew, and knew well, politicians from different political parties. Several of them contributed funds, usually illicitly, to virtually the full range of parties. Many of them had successfully lobbied opposing political parties for fairly specific benefits. Success in big business, and success as a political leader of the business class, was associated with maintaining good relationships with a wide range of senior politicians. The three political lobbyists backed up the views of the business representatives, often in the context of pointing out how the wide range of connections maintained by senior Polish businesspeople limited the potential development of professional lobbying in Poland. Politicians again claimed that they and their parties had no particular clients in the business community. However, some of them were eager to say that their political opponents had such clients, always citing recent corruption scandals. It was widely acknowledged that a minority of businesspeople was genuinely associated with political parties. These people had usually received nominations to the boards of commercial companies in which the state had a substantial or majority interest. This is consistent with the well-established influence of direct politicisation in the Polish economy.

Overall, the interview evidence favours the promiscuity hypothesis. Support for this hypothesis was strongest from the business representatives and lobbyists. Amongst the politicians there was a closer contest between the promiscuity and party-politicisation hypotheses. If the positive evidence from the qualitative interviews is added to the negative evidence from the quantitative analysis this makes for a relatively firm confirmation of the promiscuity hypothesis. The final section sums up and discusses of the wider implications of this research. 


\section{Conclusions}

This article is the first to bring a combination of high-quality quantitative and qualitative data to an investigation of the nature of networks between businesspeople and politicians in a postcommunist country. It argues that Poland's business elite is generally not as party politicised as is widely assumed. If you come across a businessperson in the corridors of a ministry or the parliament you will probably not learn much by asking with which party she is affiliated. There are two caveats to this conclusion. Poland is party politicised in the sense that the right wing seems somewhat isolated from all the other political parties who seem to share a similar business clientele. There is also evidence of party politicisation in the appointments to the boards of some firms.

Neither does the enduring influence of the Polish State in the economy clearly structure connections between leaders and senior businesspeople. However, executive experience does mean that leaders are likely to have better than average connections to the business elite. This also means that many putative business leaders are not as well connected to the wider business elite as are senior politicians. The main finding of both the statistical analyses of survey data and qualitative interviews is that there is a lack of general structure in networks of businesspeople and politicians in Poland. Relations between businesspeople and politicians are not based on loyalty to political parties. Instead, they are promiscuous.

There is no obvious way in which Poland differs from other post-communist countries in its environment for business-political relations. Thus, this research has methodological implications for studies of other post-communist countries and therefore also has implications for the understanding of business-government relations in those countries. It is a warning that politicisation and party-politicisation are not the same thing and that inferring party politicisation 
across the economy from prominent case studies may not be reliable. The argument of this article has policy implications for the battle against corruption. If party politicisation does not dominate the economy then reforming the regulations on party funding may not have the desired result. If business-political connections are promiscuous it is necessary to either eliminate the multifarious ways in which the state can privilege particular enterprises or to make sure that such decisions are not in the hands of individuals or small groups. 


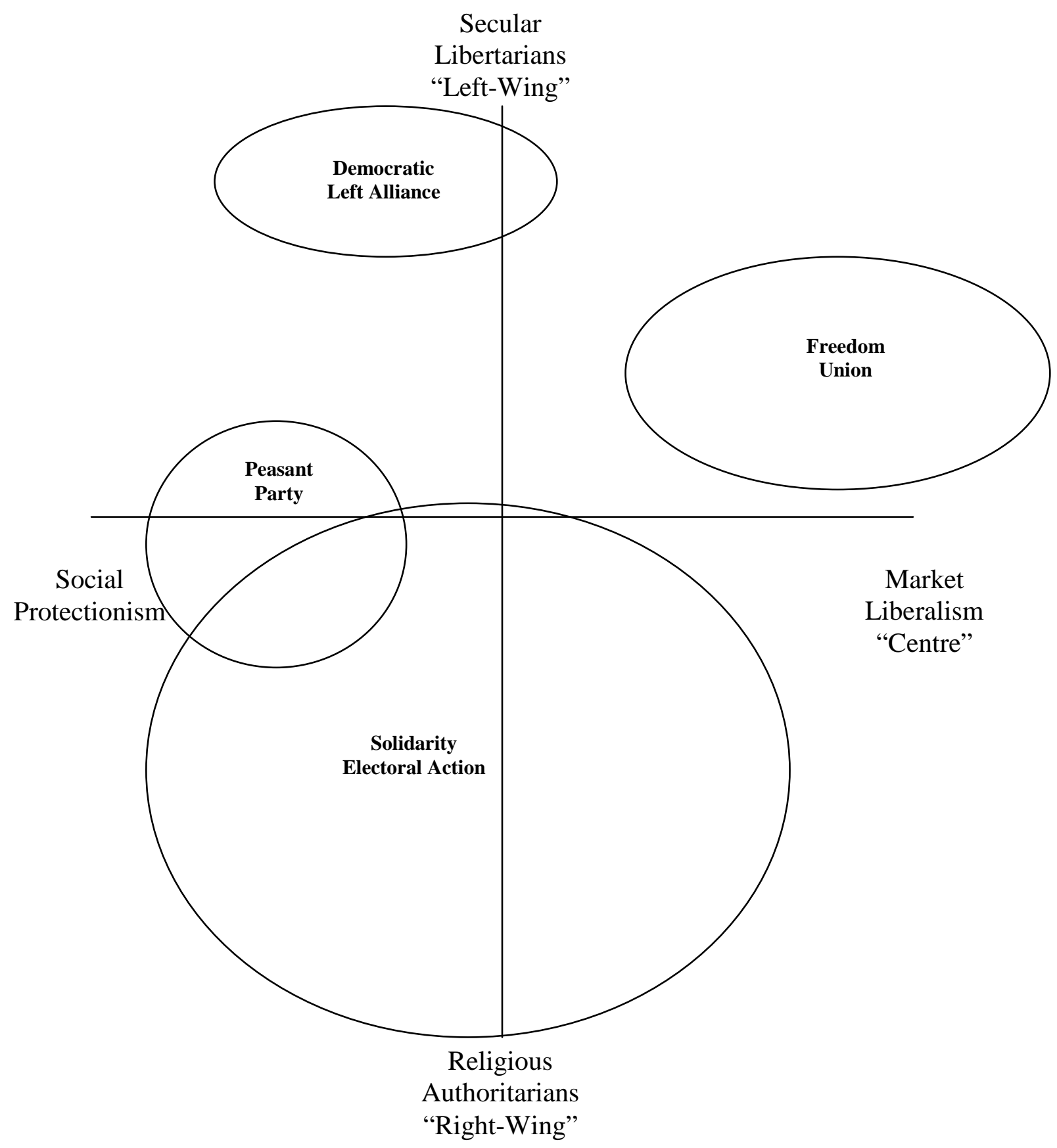

Note: This figure is based on a diagram representing an elite survey of parties in 1993 in Kitschelt, Mansfeldova, Markowski, and Tóka (1999: 233). The 1997 parties are direct descendants of the 1993 parties. They are located in the spaces occupied by their organisational predecessors in 1993.

Figure 1. Political Parties in the 1997-2001 Polish Parliament 
Table 1: Definition of variables and summary statistics

\begin{tabular}{|c|c|c|c|c|}
\hline Name & Definition & $\begin{array}{l}\text { Minimum, } \\
\text { Maximum }\end{array}$ & Mean & $\begin{array}{l}\text { Standard } \\
\text { Deviation }\end{array}$ \\
\hline Raw familiarity & $\begin{array}{l}1 \text { for knows very well, } 4 \text { for has never } \\
\text { met }\end{array}$ & 1,4 & - & - \\
\hline $\begin{array}{l}\text { Average } \\
\text { familiarity }\end{array}$ & $\begin{array}{l}\text { Familiarity score of average respondent } \\
\text { for each leader }\end{array}$ & $\begin{array}{l}3.19 \\
3.96\end{array}$ & 3.64 & 0.2 \\
\hline Business & $\begin{array}{l}1 \text { if the leader is currently primarily a } \\
\text { businessperson, } 0 \text { if not }\end{array}$ & \multicolumn{3}{|c|}{ Dummy Variable } \\
\hline Left-Right & $\begin{array}{l}0 \text { for a leader identified with the far } \\
\text { left, } 10 \text { for far right }\end{array}$ & $2.2,8.9$ & 5.9 & 1.9 \\
\hline Executive & $\begin{array}{l}\text { Number of months spent in a senior } \\
\text { state post since } 1989\end{array}$ & 0,75 & 15.7 & 19.4 \\
\hline
\end{tabular}

Table 2: Regression Analysis of "How Well Known" Leaders are

\begin{tabular}{cc}
\hline Independent Variables & Dependent Variable \\
\hline Coefficient & Average Familiarity \\
(standard error) & $3.599 * * *$ \\
Intercept & $(0.109)$ \\
& $-0.133^{*}$ \\
Business & $(0.068)$ \\
& $0.02846^{*}$ \\
Left-Right & $(0.015)$ \\
Executive & $-0.00552^{* * *}$ \\
& $(0.002)$ \\
$\mathrm{R}^{2}$ & 0.353 \\
& $5.639 * * *$ \\
$\mathrm{~F}$ &
\end{tabular}

Notes: Model is Ordinary Least Squares. $\mathrm{N}=35$.

*** significant at the $1 \%$ level, ** significant at $5 \%$, * significant at $10 \%$ 
Table 3: Regression Analysis of Scaling Solution

\begin{tabular}{ccccc}
\hline $\begin{array}{c}\text { Independent } \\
\text { Variables }\end{array}$ & \multicolumn{4}{c}{ Dependent Variables } \\
\hline Coefficient & Dimension 1 & Dimension 2 & Dimension 3 & Dimension 4 \\
(standard error) & -0.763 & $-6.947 * *$ & 3.801 & $7.818^{*}$ \\
Intercept & $(2.615)$ & $(3.262)$ & $(3.878)$ & $(2.621)$ \\
& 0.366 & $1.672^{* * *}$ & -1.098 & $-2.653^{*}$ \\
Average Familiarity & $(0.716)$ & $(0.894)$ & $(1.062)$ & $(0.718)$ \\
& $2.122^{*}$ & 0.165 & -0.174 & $0.493^{* * *}$ \\
Business & $(0.289)$ & $(0.361)$ & $(0.429)$ & $(0.29)$ \\
Left-Right & $-0.226^{*}$ & $0.154^{* * *}$ & 0.08162 & $0.255^{*}$ \\
& $(0.065)$ & $(0.081)$ & $(0.096)$ & $(0.065)$ \\
Executive & 0.006197 & -0.006561 & -0.01493 & 0.0109 \\
& $(0.008)$ & $(0.01)$ & $(0.012)$ & $(0.08)$ \\
$\mathrm{R}^{2}$ & 0.735 & 0.358 & 0.078 & 0.542 \\
$\mathrm{~F}$ & $20.81^{*}$ & $4.184^{*}$ & 0.636 & $8.872^{*}$
\end{tabular}

Notes: Regression model is Ordinary Least Squares. Dimensions from 4-dimensional scaling solution. $\mathrm{N}=35 *$ significant at the $1 \%$ level, $* *$ significant at $5 \%, * * *$ significant at $10 \%$

Table 4: Interpretation of Cluster Analysis

\begin{tabular}{cccc}
\hline Variables & Cluster 1 & Cluster 2 & Clusters 3 \& 4 \\
\hline $\begin{array}{c}\text { Above Average } \\
\text { Familiarity }\end{array}$ & All 5 below & 14 above, 9 below & $\begin{array}{c}\text { 2 above, 5 } \\
\text { below }\end{array}$ \\
Senior State Experience & 3 Yes, 2 No & 17 Yes, 6 No & 7 No \\
$\begin{array}{c}\text { Political affiliation \& } \\
\text { business activity }\end{array}$ & All 5 Right-wingers & $\begin{array}{c}\text { 6 Left-wingers, } \\
\text { 5 Businesspeople, }\end{array}$ & $\begin{array}{c}7 \\
\text { 5 Centrists, 8 others }\end{array}$ \\
\hline
\end{tabular}

Notes: Clustering method is complete linkage. $\mathrm{N}=35$. The justification for joining clusters 3 and 4 is that they are relatively small and join together at the next level of the hierarchical agglomerative process (see Dendrogram in Appendix). 


\section{Appendix: List of Leaders}

\author{
Arendarski, Andrzej \\ Balcerowicz, Leszek \\ Bielecki, Czesław \\ Bochniarz, Henryka \\ Borowksi, Marek \\ Cimoszewicz, Włodzimierz \\ Geremek, Bronisław \\ Goryszewski, Henryk \\ Gronkiewicz-Waltz, Hanna \\ Gudzowaty, Aleksander \\ Kaczmarek, Wiesław \\ Kaczyński, Jarosław \\ Kluska, Roman \\ Krzaklewski, Marian \\ Kwaśniewski, Aleksander \\ Lewandowski, Janusz \\ Miazek, Ryszard \\ Miller, Leszek \\ Niemczycki, Zbigniew \\ Olesiak, Kazimierz \\ Paga, Lesław \\ Pawłak, Waldemar \\ Pol, Marek \\ Rokita, Jan Maria \\ Siwiec, Marek \\ Skowroński, Andrzej \\ Sobolewski, Zbigniew \\ Solorz, Zygmunt \\ Suchocka, Hanna \\ Syryjczyk, Tadeusz \\ Tomaszewski, Janusz \\ Walendziak, Wiesław \\ Wałęsa, Lech \\ Wołek, Tomasz \\ Zaraska, Witold
}

Polish Chamber of Commerce

Freedom Union

Solidarity Electoral Action

Polish Business Roundtable

Democratic Left Alliance

Democratic Left Alliance

Freedom Union

Peasant Party

Polish Central Bank

Bartimpex

Democratic Left Alliance

Solidarity Electoral Action

Optimus

Solidarity Trade Union

Democratic Left Alliance

Freedom Union

Peasant Party

Democratic Left Alliance

Curtis Group

Bank Gospodarki Żywnościej

Warsaw Stock Exchange

Peasant Party

Union of Labour

Solidarity Electoral Action

Democratic Left Alliance

Elektrim

BIG Bank Gdański

Polsat

Freedom Union

Freedom Union

Solidarity Electoral Action

Solidarity Electoral Action

Christian Democracy of the Third Republic

Życie Warszawy

Exbud 


\section{Appendix: Cluster Analysis}

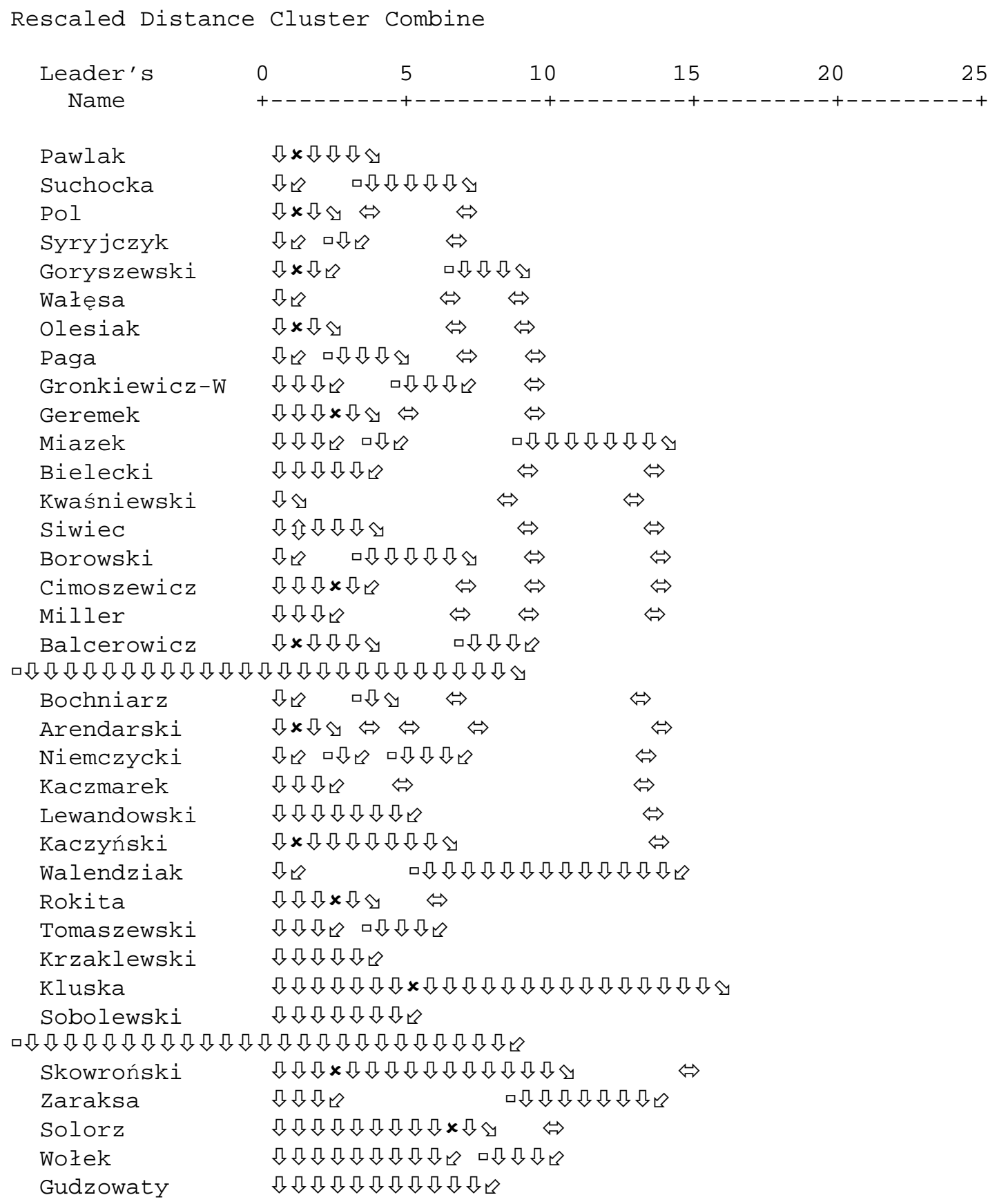

$\Leftrightarrow$

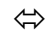

$\Leftrightarrow$

$\Leftrightarrow$

$\Leftrightarrow$

$\Leftrightarrow$

$\Leftrightarrow$ $\Leftrightarrow$

$\Leftrightarrow$

$\Leftrightarrow$

Figure 2: Dendrogram from Complete Linkage 


\section{Notes}

${ }^{1}$ Only one party tends to rate itself differently than do its supporters. This is the Labour Union which is represented here by Marek Pol. The Labour Union claims to be left of the Democratic Left while its supporters clearly rate it as well right of the Democratic Left. Basically, the Labour Union holds to the classic Western European conception of the left-right continuum as defined by economic policy while its supporters conceive of the left-right continuum in a similar way to other Poles. In terms of social distance, which is the dependent variable under examination, the Polish interpretation makes more sense (Szawiel 1999).

2 Two individuals do not fit comfortably into either the business or the political categories. They are Hanna Gronkiewicz-Waltz, the Governor of the Polish Central Bank and Tomasz Wołek, the editor of Życie Warszawy newspaper. They have been given the mean score for managers from the Polish Election survey.

\section{References}

Ágh, A. (1998). Politics in Central Europe. London: Sage

Drąg, Z. (1999). Elita biznesu: Autonomiczny segment elity politycznej? in Wasilewski, J. (ed.), Elita Polityczna 1998. Warsaw: Institute of Political Studies, Polish Academy of Sciences, pp. 57-74

Draus, F. (2000). Les organisations patronales dans les pays de l'Europe centrale et orientale. Brussels: European Trade Union Institute

Dzwończyk, J. \& Sobczyk, S. (1995). Employer and Entrepreneur Organisations during the Transformation Period in Poland in Hausner, J., Pedersen, O. \& Ronit, R. (eds.) Evolution of Interest Representation and Development of the Labour Market in Post-Socialist Countries. Cracow: Cracow Academy of Economics, pp. 141-157

European Journal of Political Research. (1990-99). EJPR, Political Data Yearbook

Frentzel-Zagórska, F. (2000). Structure of the Polish Political Scene as Seen by the Elite in Frentzel-Zagórska, J. \& Wasilewski, J. (eds.), The Second Generation of Democratic Elites in Central and Eastern Europe. Warsaw: Institute of Political Studies, Polish Academy of Sciences, pp. 217-232

Golden, M. A. \& Chang, E. C.C. (2001). Competitive Corruption: Factional Conflict and Political Malfeasance in Postwar Italian Christian Democracy, World Politics, 53: 588-622

Heinz, J. P., Laumann, E. O., Nelson, R. L. \& Salisbury, R. H. (1993). The Hollow Core: Private Interests in National Policy-Making. Cambridge, MA: Harvard University Press

Hellman, J. S., Jones, G. \& Kaufmann, D. (2000). Seize the State, Seize the Day: State Capture, Influence and Corruption in Transition, World Bank Policy Research Working Paper, 2444

Hughes, J., John, P. \& Sasse, G. (2002). From plan to network: Urban elites and the post-communist organisational state in Russia, European Journal of Political Research, 41: 395-420

Jasiecki, K. (1997). Organizacje pracodawców i przedsiębiorców w Polsce in J. Wasilewski (ed.), Zbiorowi Aktorzy Polskiej Polityki. Warsaw: Instytut Studiów Politycznych Polskiej Akademii Nauk, pp. 167-202

Jasiecki, K. (2000). Lobbying Gospodarcze w Polsce. Unpublished. Warsaw: Instytut Filozofii i Socjologii, Polska Akademia Nauk

Jasiecki, K. (2001). Elita Biznesu w Polsce: Drugie Narodziny Kapitalizmu. Warsaw: Instytut Filozofii i Socjologii, Polska Akademia Nauk

Kitschelt, H., Mansfeldova, Z, Markowski, R \& Tóka, G (1999). Post-Communist Party Systems: Competition, Representation, and Inter-Party Cooperation (Cambridge: Cambridge University Press 
Knoke, D, Pappi, F. U., Broadbent, J. \& Tsujinaka, Y (1996). Comparing Policy Networks. Cambridge: Cambridge University Press

Kozek, W. (1999). Społeczne Organizacje Biznesu w Polsce a Stosunki Pracy. Warsaw: Centrum Partnerstwa Społecznego

Lewis, P. (2000). Political Parties in Post-Communist Eastern Europe. London: Routledge

McMenamin, I. (2002). Polish Business Associations: Flattened Civil Society or Super Lobbies?, Business and Politics, 4: 299-315

Olson, M. (2000). Power and Prosperity: Outgrowing Communist and Capitalist Dictatorships. New York: Basic Books

Organisation for Economic Co-operation and Development (1997). OECD Economic Survey: Poland. Paris: OECD

Padgett, S. (2000). Organizing Democracy in Eastern Germany: Interest groups in post-communist society. Cambridge: Cambridge University Press

Rzeczpospolia. Archive, www.rzeczpospolita.pl

Rzeczpospolita (2000a). Rzeczpospolita, Kraj, 6 December

Rzeczpospolita (2000b). Rzeczpospolita, Opinie, 9-10 December

Schoenman, R. (2002a). Captains or Pirates? The New Economic Elite and their Role in Poland's Economic Development, paper delivered at the Conference for Europeanists, Chicago

Schoenman, R. (2002b), Webs of Transition: State-Economy Relations in Romania, Bulgaria and Poland, paper delivered at the American Political Science Association Annual Meeting, Boston

Shleifer, A. \& Vishny, R. W. (1998). The Grabbing Hand: Government Pathologies and their Cures. Cambridge, MA: Harvard University Press

Staniszkis, J. (1991). The Breakthrough in Eastern Europe: The Case of Poland. Berkeley: University of California Press

Staniszkis, J. (1998). Post-Communism: The Emerging Enigma. Warsaw: Institute of Political Studies, Polish Academy of Sciences

Stark, D. \& Bruszt, L. (1998). Postsocalist Pathways: Transforming Politics and Property in East-Central Europe Cambridge: Cambridge University Press

Szawiel, T. (1999). Zróznicowanie w lewicowo-prawicowe i jego korelaty in Markowski, R. (ed.), Wybory Parlamentarne 1997: System Partyjny, postawy polityczne, zachowanie wyborcze. Warsaw: Institute of Political Studies, pp. 111-148

Szczerbiak, A. (2000). Testing Party Models in East-Central Europe: Local Party Organization in Post-Communist Poland, Studia Polityczne. 10: 85-106

Szelényi, I. \& Szelényi, S. (1995). Circulation or reproduction of elites during the postcommunist transformations of Eastern Europe: Introduction, Theory and Society. 24: 615-638

Wasilewski, J. (1994). La nomenklatura: vers quel destin social?, Revue d'études comparatives Est-Ouest, 25: 34-46

Wasilewski, J. (2000), Polish Post-Transitional Elite in Frentzel-Zagórska , J. \& Wasilewski, J. (eds.) The Second Generation of Democratic Elites. Warsaw: Institute of Political Studies, Polish Academy of Sciences, pp. $197-$ 216 
World Bank. (2003). Governance Data. www.worldbank.org/governance 